\title{
Nutritional Deficiencies of Yams (Dioscorea spp.) and Related Effects on Yield and Leaf Composition'
}

\author{
Socorro Gazlambide and Héctor R. Cibes ${ }^{2}$
}

\begin{abstract}
Deficiencies in the nutrition of the yam (Dioscorea rotundata) cultivar Habanero were studied in the greenhouse using sand culture. Symptoms were produced by the omission in the nutrient solution of one of each of the following elements: nitrogen, phosphorus, potassium, calcium, sulfur, magnesium, iron, manganese, and boron. Lack of nitrogen, phosphorus, potassium, calcium, or sulfur restricted growth and tuber yield significantly. The most striking foliar symptoms were produced in plants lacking potassium. Necrotic spots, which appeared along the margins of well developed leaves, soon coalesced and produced rolling of margins and tips. In advanced stages, the whole plant showed a burnt appearance followed by shedding of foliage. Plants lacking magnesium showed an exhuberant growth despite developing a marked interveinal chlorosis in the older leaves on the bottom half of the plant and tuber formation was negligible. Lack of calcium caused deformation and severe damage to the skin of tubers which were rough and corky. Lack of iron, manganese, and boron resulted in significantly reduced growth and tuber formation. Mild chlorosis appeared in leaves of minus iron and manganese treatments. Lack of boron caused brown rot inside the tubers. Leaf analyses indicated that omission of some nutrient elements influenced the absorption of others and/or their accumulation in the leaves.
\end{abstract}

\section{INTRODUCTION}

Yams (Dioscorea rotundala and D. alata) are the most important starchy root crops of Puerto Rico. Yam protein content is low but the tubers supply substantial amounts of minerals and vitamin $C$ to the diet. Although yam cultivation in Puerto Rico has been restricted to small farms in the mountain region, there was a production of $270,000 \mathrm{cwts}$ in 1973-74 with a market value exceeding 5 million dollars. This production supplied the local market and permitted small shipments to the United States. Adoption of improved cultural practices, including proper nutrition, would help improve both yield and quality of yams.

1 Manuscript submitted to Editorial Board December 13, 1974.

2 Assistant Chemist and Plant Physiologist, respectively, Agricultural Experiment Station, Mayagüez Campus, University of Puerto Rico, Río Piedras, P.R. 
Nutritional deficiency symptoms of yams have not been studied previously in Puerto Rico. This paper describes the visual symptoms produced on the Habanero cultivar of Dioscorea rotundata by the omission of macro and micronutrient elements from the nutrient solution. The effects of each deficiency on plant tissue composition, growth and yield also are discussed. These visual symptoms will aid researchers, extension workers and progressive farmers in field recognition of such deficiencies.

\section{MATERIALS AND METHODS}

In this study, as well as in others conducted previously, ${ }^{3}$ the sand culture technique was used to develop deficiency symptoms in the yam. For this purpose, 30 five-gallon self-drained glazed stone crocks were filled with fine white quartz sand. Nutrient impurities were washed out from the sand by leaching it separately with a 3 percent solution of $\mathrm{HCl}$ followed by a 3 percent solution of $\mathrm{NaOH}$. Finally, the sand was rinsed, first with tap water until clear, then with distilled water. It was assumed this treatment left the sand free from organic matter and inorganic impurities.

The planting material used was obtained from apparently virus-free plants. Most edible yams produce flowers but rarely and almost never produce seeds. They are propagated commercially from small tubers or pieces of tubers. However, our experimental material consisted of plantlets developed in a propagator from three-inch, one-internode vine cuttings bearing a pair of well developed and healthy-looking leaves. Three weeks after rooting, plantlets were thoroughly washed and transplanted one each to the glazed crocks. Treatments were started two weeks after transplanting.

Nutrient solutions were prepared with deionized water obtained from an Ilco-Way De-ionizer. The concentrations of the major elements in the control solution expressed in milligram equivalents per liter of solution were: $\mathrm{Ca}, 9 ; \mathrm{Mg}, 4.5 ; \mathrm{K}, 2.3 ; \mathrm{NO}_{3}, 9 ; \mathrm{PO}_{4}, 6.9 ;$ and $\mathrm{SO}_{4}, 4.5$. In the deficient solutions $\mathrm{Na}$ replaced $\mathrm{K}$ and $\mathrm{Mg} ; \mathrm{K}$ replaced $\mathrm{Ca} ; \mathrm{Cl}$ replaced $\mathrm{SO}_{4}$ and $\mathrm{NO}_{3} ; \mathrm{SO}_{4}$ replaced $\mathrm{PO}_{4}$ at equivalent concentrations. Microelements were supplied as parts per million: $\mathrm{Fe}, 10 ; \mathrm{B}, 0.5 ; \mathrm{Mn}, 0.5 ; \mathrm{Zn}, 0.05$; and $\mathrm{Cu}, 0.02$. Iron was supplied as iron sequestrene and boron, manganese, zinc and copper as sulfates, except in the minus sulfur treatment in which these elements were supplied as chlorides.

Solutions were freshly prepared three times a week from 0.5 molar stock solutions. Two liters were applied per pot. Treatments were replicated three times in a randomized arrangement. Leaf samples for tissue analysis were taken just prior to harvest time, six months after planting.

3 Cibes, H. R., and Samuels, G., Mineral deficiency symptoms displayed by coffee trees grown under controlled conditions. Agr. Exp. Sta., Univ. P.R., Tech. Paper 14, 1955. 


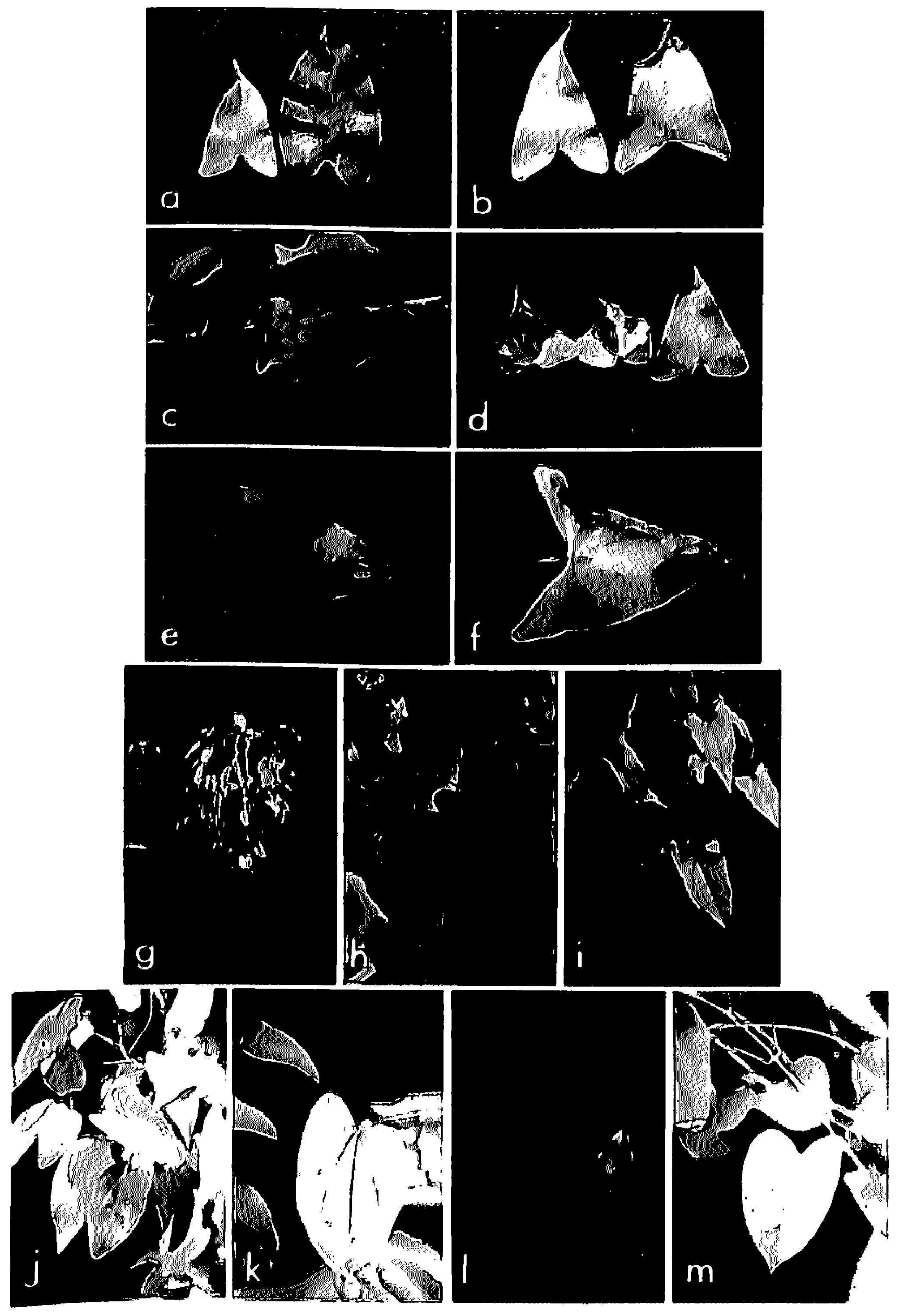

Fig. 1 


\title{
RESULTS AND DISCUSSION
}

\author{
VISUAL DEFICIENCY SYMPTOMS
}

\section{Nitrogen}

Plants lacking nitrogen produced very small leaves of a light green to yellowish color. This chlorosis appeared first on the older leaves (fig. 1, A). In advanced stages, leaves dried out beginning at the tips and along the margins, and finally abscissed (fig. 1, B). New leaves were very thin and translucent, and showed a purplish color. Chlorosis finally appeared in the new growth without abscission of the leaves.

\section{Phosphorus}

The omission of phosphorus produced leaves of a dark green color with a shiny luster when mature and with a purple pigmentation when young. Older leaves developed yellow and light brown areas scattered over the lamina (fig. 1, C). In advanced stages, these areas turned dark brown on a completely yellow leaf (fig. 1, D). Final shedding of the foliage occurred along the vine from the base upwards.

\section{Potassium}

The first symptom of potassium deficiency appeared as small brownish round spots on leaves of normal size and color (fig. 1, E). These areas enlarged rapidly and coalesced, especially along the margins, which finally dried out and rolled inwards (fig. 1, F). At this stage, the leaves turned yellow, with large necrotic areas giving them a burnt appearance. All plants

Fig. 1.-A, Nitrogen deficient leaf on the left showing light green to yellow color and small size compared to a normal leaf on the right; $B$, Advanced stage of nitrogen deficiency shown by the leaf on the right displaying necrosis and curling of the tip. Leaf on the left shows the first symptom of the deficiency; C, Early symptoms of phosphorus deficiency shown by yellow and light brown areas scattered over the lamina; D, Advanced stages of phosphorus deficiency shown by the two leaves on the left by dark brown areas on a complete yellow leaf. Leaf on the right shows early symptoms of the deficiency; E, Early symptom of potassium deficiency as small brownish spots appearing on normal leaves; F, Advanced stage of potassium deficient leaf showing large necrotic areas and rolling upward of margin and tip; $G$, Potassium deficient plant showing a large number of necrotic leaves giving the foliage a burnt appearance; $H$, Magnesium deficient leaves showing yellowing of the leaves. Note that only the veins remained green; I, Shoestringing in the new growth of magnesium deficient plants; J, Sulfur deficient plant showing general yellowing of the foliage; $K$, Calcium deficient leaf showing small necrotic spots and necrosis along the veins on the underside of the leaf; $L$, Iron deficient leaf on the right showing a mild chlorosis compared to a normal green leaf on the left; M, Manganese deficient leaf showing a mottled chlorosis in interveinal tissue 
were uniformly affected. Shedding of the leaves followed shortly after. Lack of potassium produced the most severe foliar symptoms (fig. 1, G).

\section{Magnesium}

The first symptom of magnesium deficiency was an interveinal chlorosis of the basal leaves. The chlorosis appeared near the leaf base, progressing towards the center of the lamina and upwards, until the whole leaf was affected. Only the veins remained green (fig. 1, H). In advanced stages, small necrotic spots appeared on the lamina. Shoestringing appeared in the new growth as a final symptom (fig. 1, I).

\section{Sulfur}

Lack of sulfur produced a generalized yellowing of the foliage. The whole lamina, including the veins, turned light green to yellow. Leaves were narrower than those of the normal plants (fig. $1, \mathrm{~J}$ ).

\section{Calcium}

Plants lacking calcium developed a yellow mottling in the older leaves. Leaves were leathery and smaller than normal. In advanced stages, necrosis appeared along the main veins on the underside of the leaf (fig. 1, K).

\section{Iron}

Symptoms of iron deficiency were very mild. An interveinal chlorosis was evident in the new leaves. Mature leaves were of a light green to yellow color (fig. 1, L).

\section{Manganese}

Deficiency symptoms appeared as a mottled chlorosis in interveinal tissues of the leaves (fig. $1, M$ ).

\section{Boron}

No foliar symptoms of boron deficiency were observed.

$$
\text { GROWTH AND YIELD }
$$

The effect of deficiencies of various elements on growth and yield of plants are shown in table 1.

\section{Nitrogen}

Growth of plants was restricted severely by the lack of nitrogen. Plants developed an unbranched main stem bearing very small leaves. Omission of nitrogen produced the lowest top growth of all treatments as well as negligible tuber formation. 


\section{Phosphorus}

Lack of phosphorus affected growth severely. Plants produced unbranched main stems bearing leaves smaller than normal. Tuber yield was very poor, ranking third after nitrogen and magnesium.

\section{Polassium}

Omission of potassium affected top growth adversely. Plants developed normally until the first deficiency symptoms appeared. In a short time all

TABLE 1.-Effect of the omission of essential elements in nutrient solution on the top growth and tuber yield of yam plants ${ }^{1}$

\begin{tabular}{ccc}
\hline Treatment & Top weight & Tuber yield \\
\hline & & Grams \\
Complete solution & 590.67 & 1002.67 \\
$-\mathrm{N}$ & $9.33^{* *}$ & $9.00^{* *}$ \\
$-\mathrm{P}$ & $45.33^{* *}$ & $91.67^{* *}$ \\
$-\mathrm{K}$ & $229.00^{* *}$ & $239.33^{* *}$ \\
$-\mathrm{Ca}$ & $105.00^{* *}$ & $163.67^{* *}$ \\
$-\mathrm{Mg}$ & $667.67^{*}$ & $38.00^{* *}$ \\
$-\mathrm{S}$ & $226.00^{* *}$ & $309.67^{*}$ \\
$-\mathrm{Fe}$ & $426.33^{*}$ & $965.33^{*}$ \\
$-\mathrm{Mn}$ & $450.00^{*}$ & $840.00^{*}$ \\
$-\mathrm{B}$ & $419.00^{*}$ & $820.67^{*}$ \\
\hline
\end{tabular}

1 Values are means of three replicates.

** Difference between omitted element and control (complete solution) significant at the 1-percent level.

* Difference between omitted element and control significant at the 5-percent level.

the foliage was affected showing a burnt appearance. Shedding of leaves followed shortly after. Tuber yield was markedly reduced.

\section{Magnesium}

Plants lacking magnesium showed an exhuberant top growth, exceeding those receiving a complete solution. In contrast, tuber formation markedly reduced, producing the second lowest yield.

\section{Calcium}

Lack of calcium severcly restricted growth. Tuber yield was markedly reduced. Tuber quality was greatly affected as shown by the shape of tubers and the texture of the skin. Tubers were flattened in contrast to the cylindrical form characteristic of the variety. The skin was of a rough, corky texture and had cracks throughout the surface. 


\section{Sulfur}

Growth of plants and tuber production were severely affected by the lack of sulfur. Tubers were cylindrical and smooth.

Iron

Lack of iron restricted growth considerably. Tuber yield was high, however, second to that of plants receiving a complete solution. A similar investigation with sweetpotatoes ${ }^{4}$ showed the omission of iron did not affect the production of edible roots.

\section{Manganese}

Omission of manganese affected growth significantly. Tuber production was outyielded only by plants receiving the complete solution and by those in the minus iron treatments. Tubers were cylindrical and had a smooth skin.

\section{Boron}

Lack of boron did not affect growth of plants appreciably. Tuber yield was high. Tubers were shorter and broader than the cylindrical forms characteristic of the variety. A brown rot in the center of the tubers affected quality.

\section{LEAF ANALYSES}

The results of leaf analyses are presented in table 2. The omission of each individual element in the nutrient solution resulted in a significant reduction in its leaf content, with the exception of iron and manganese. These low levels correspond to the deficiency symptoms observed in the plants. Lack of certain nutrient elements influenced the absorption of others and/or their accumulation in the leaves.

\section{Nitrogen}

Nitrogen level was drastically reduced when nitrogen was omitted from the nutrient solution. The highest level of this element was found in the minus sulfur plants. Omission of magnesium was also associated with increased nitrogen content. All other treatments showed significantly higher levels of nitrogen compared to the minus nitrogen plants. Lack of nitrogen was associated with accumulation of iron and manganese, a high level of potassium, and with low levels of phosphorus, calcium, magnesium, and sulfur.

- Cibes, H. R., and Samuels, G., Mineral deficiency symptoms displayed by sweetpotato plant grown under controlled conditions. Agr. Exp. Sta., Univ. P.R., Tech. Paper 20, 1957. 


\section{Phosphorus}

Omission of phosphorus resulted in the lowest phosphorus level. The highest concentration of this element was associated with lack of potassium. Lack of nitrogen, calcium, and sulfur reduced phosphorus level significantly. Lack of phosphorus was associated with accumulation of potassium, high levels of nitrogen, manganese, and iron, and low levels of calcium, magnesium, sulfur, and boron.

TABLE 2.-Effect of the omission of essential elements in the nutrient solution on the chemical composition of yam leaves ${ }^{1}$

\begin{tabular}{|c|c|c|c|c|c|c|c|c|c|}
\hline \multirow{2}{*}{ Treatment } & \multicolumn{9}{|c|}{ Macro and microelement content in leaf tissue } \\
\hline & $\begin{array}{l}\mathbf{N} \\
\%\end{array}$ & $\underset{\%}{P}$ & $\frac{\mathrm{K}}{\%}$ & $\begin{array}{l}\mathrm{Ca}_{\mathrm{a}} \\
\%\end{array}$ & $\underset{\%}{\mathrm{Mg}}$ & $\begin{array}{l}\mathbf{S} \\
\%\end{array}$ & $\underset{\mathrm{ppm}}{\mathrm{Fe}}$ & $\underset{\mathbf{p p m}}{\mathbf{M n}}$ & $\underset{\mathrm{ppm}}{\mathrm{B}}$ \\
\hline $\begin{array}{l}\text { Complete } \\
\text { solution }\end{array}$ & $2.37^{* *}$ & $0.57^{* *}$ & 0.58 & $5.28^{* *}$ & $0.98^{* *}$ & $0.53^{* *}$ & 261.7 & 231.4 & $108.6^{* *}$ \\
\hline$-\mathbf{N}$ & 0.95 & 0.26 & 1.18 & $2.59^{* *}$ & 0.46 & 0.23 & $663.2^{* *}$ & $490.0^{*}$ & - \\
\hline$-\mathbf{P}$ & $2.60^{* *}$ & 0.12 & $3.27^{* *}$ & $2.24^{* *}$ & $0.53^{*}$ & 0.21 & $355.7^{*}$ & 323.4 & 58.7 \\
\hline$-\mathbf{K}$ & $2.88^{* *}$ & $0.73^{* *}$ & 0.30 & $5.35^{* *}$ & $1.39 * *$ & $0.30^{*}$ & 167.7 & 169.4 & $92.3^{* *}$ \\
\hline$-\overline{\mathrm{Ca}}$ & $2.68^{* *}$ & $0.39^{* *}$ & $2.61 * *$ & 0.51 & $1.43^{* *}$ & 0.23 & 85.0 & 276.4 & $70.3^{* *}$ \\
\hline$-S$ & $4.92^{* *}$ & $0.41^{* *}$ & $1.10^{*}$ & $5.03^{* *}$ & $0.87^{* *}$ & 0.13 & 147.0 & 308.7 & $74.0^{* *}$ \\
\hline$-\mathbf{M g}$ & $3.30^{* *}$ & $0.57^{* *}$ & $3.00 * *$ & $2.33^{* *}$ & 0.18 & 0.22 & 93.7 & 138.4 & 48.0 \\
\hline$-\mathrm{Fe}$ & $2.69^{* *}$ & $0.54^{* *}$ & 0.67 & $5.27^{* *}$ & $0.90^{* *}$ & $0.38^{* *}$ & 119.3 & 299.7 & $96.3^{* *}$ \\
\hline$-\mathbf{M n}$ & $2.74^{* *}$ & $0.50^{* *}$ & 0.66 & $4.73^{* *}$ & $0.90^{* *}$ & $0.42^{* *}$ & 143.7 & 238.4 & $83.3^{* *}$ \\
\hline$-B$ & $2.80^{* *}$ & $0.47^{* *}$ & 0.56 & $5.55^{* *}$ & $1.04^{*}$ & $0.40^{* *}$ & 121.3 & 149.4 & 42.0 \\
\hline
\end{tabular}

1 Values are means of three replicates.

** Difference between omitted element and other treatments significant at the 1-percent level

* Difference between omitted element and other treatments significant at the 5percent level.

\section{Potassium}

Lack of potassium produced the lowest potassium level while the highest concentration of the element occurred when phosphorus was omitted. Plants lacking magnesium and calcium also accumulated potassium to significant levels. Lack of potassium was associated with accumulation of phosphorus, magnesium, nitrogen, calcium, and boron and with low levels of iron, manganese, and sulfur.

\section{Calcium}

Calcium content was significantly reduced when this element was omitted from the nutrient solution. High levels occurred in the absence of iron, boron, potassium and sulfur, and low levels in the minus nitrogen, phos- 
phorus, and magnesium. Lack of calcium was associated with accumulation of potassium and magnesium and low levels of iron and sulfur.

\section{Sulfur}

Plants grown in the absence of sulfur had the lowest sulfur level. Lack of nitrogen, phosphorus, calcium and magnesium also resulted in low sulfur levels. Omission of sulfur was associated with accumulation of nitrogen; high levels of potassium, calcium and manganese and a low level of iron.

\section{Magnesium}

Lack of magnesium resulted in the lowest magnesium content while the omission of calcium and potassium resulted in accumulation of this element. Omission of magnesium resulted in accumulation of potassium and nitrogen, and reduced levels of calcium, sulfur, manganese, iron, and boron. Lack of nitrogen and phosphorus were associated with low magnesium levels.

\section{Iron}

The omission of iron did not bring about the lowest iron level. Iron content was lowest in the absence of calcium and magnesium while the omission of nitrogen and phosphorus resulted in accumulation of iron.

\section{Manganese}

The lowest manganese level occurred in the minus magnesium treatment rather than in the minus manganese level. Lack of boron and potassium also resulted in low manganese levels. The omission of either nitrogen or phosphorus was associated with an accumulation of manganese.

\section{Boron}

The omission of boron resulted in the lowest boron level. Absence of magnesium and phosphorus were associated with low boron contents. The highest boron level was produced in the complete solution. Lack of iron and potassium were also associated with high levels of boron. Omission of this element was associated with high levels of calcium and magnesium and low levels of manganese and iron.

\section{RESUMEN}

Se estudiaron en el invernadero, usando el método de cultivo en arena, las carencias nutricionales del cultivar ñame Habanero (Dioscorea rotundata). Los síntomas característicos de cada carencia se indujeron al omitir en la solución nutritiva uno de los siguientes elementos: nitrógeno, fósforo, potasio, calcio, azufre, magnesio, hierro, manganeso y boro. Las carencias de nitrógeno, fósforo, potasio, calcio y azufre redujeron significativamente el crecimiento de las plantas y la formación de tubérculos. La de potasio causó los síntomas foliares más acusados. Estos empezaron a mani- 
festarse como pequeñas manchas necróticas en el margen de hojas de desarrollo aparentemente normal. Estas manchas rápidamente se fundieron y produjeron una quemazón y enrollamiento de las hojas causando finalmente su caída. La ausencia de magnesio causo clorosis intervenal en las hojas desde la base hasta la mitad de la planta. Estas plantas crecieron exhuberantemente, pero, sin embargo, no formaron tubérculos. La carencia de calcio disminuyó la producción de tubérculos y les afectó la calidad al causar deformación y formar una piel rugosa con apariencia de corcho. La falta de hierro, manganeso y boro disminuyó significativamente el crecimiento de las plantas y la formación de tubérculos. Los tubérculos procedentes de plantas carentes de boro mostraron lesiones centrales de color pardo. 